\title{
Rescue cardiac transplantation for early failure of the Fontan-type circulation in children
}

Milind Chaudhari, MD

Jon Sturman, FRCA ${ }^{\mathrm{b}}$

John O'Sullivan, FRCP Ia

Jon Smith, FRCA ${ }^{\mathrm{C}}$

Neil Wrightson, $\mathrm{BSc}^{\mathrm{d}}$

Gareth Parry, FRCP

David Bolton, FRCA ${ }^{\mathrm{C}}$

Simon Haynes, FRCA ${ }^{\mathrm{C}}$

Leslie Hamilton, FRCS ${ }^{f}$

Asif Hasan, FRCS ${ }^{f}$
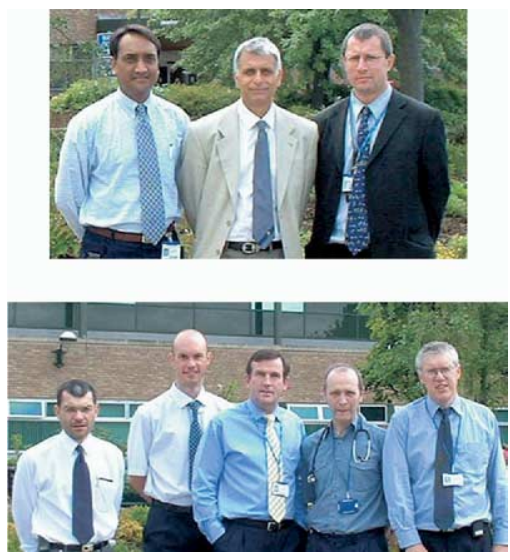

Top photo, left to right: Chaudhari, Hasan, Haynes. Bottom photo, left to right: Parry, Sturman, Hamilton, O'Sullivan, Smith.

From the Department of Paediatric Cardiology, ${ }^{\text {a }}$ the Department of Paediatric Anaesthesiology, ${ }^{\mathrm{b}}$ the Department of Paediatric Cardio-thoracic Anaesthesiology, ${ }^{c}$ Transplant Coordinator, the Department of CardioThoracic Transplantation, ${ }^{\mathrm{d}}$ the Department of Cardiac Transplantation, ${ }^{\mathrm{e}}$ and the Department of Paediatric Cardiac Surgery, Freeman Hospital, ${ }^{f}$ Newcastle upon Tyne, United Kingdom.

Received for publication April 26, 2004; revisions received June 10, 2004; accepted for publication June 14, 2004

Address for reprints: Milind Chaudhari, MD, Freeman Hospital, Newcastle upon Tyne, NE 7 7DN, United Kingdom (E-mail: milind. chaudhari@nuth.northy.nhs.uk).

J Thorac Cardiovasc Surg 2005;129:416-22 0022-5223/\$30.00

Copyright (C) 2005 by The American Association for Thoracic Surgery

doi:10.1016/j.jtcvs.2004.06.030
Objective: Early failure of the Fontan-type circulation is a potentially fatal complication. We review our experience with cardiac transplantation in children presenting with end-stage heart failure in this scenario.

Methods: We performed a retrospective review. Between 1985 and 2003, 6 children aged less than 16 years were referred for cardiac transplantation. The indication for cardiac transplantation was end-stage cardiac failure early after the completion of the Fontan-type operation.

Results: All 6 patients listed for transplantation underwent cardiac transplantation; the median interval to transplantation from the operation was 36 days (range, 6-180 days). Four patients had undergone the Fontan procedure, and 2 had one-and-ahalf-ventricle repair. All 6 patients were ventilated and inotrope dependant, with varying degrees of multiorgan dysfunction. One patient was bridged to transplantation with extracorporeal membrane oxygenation. The median age at transplantation was 7.1 years (range, 3-12.5 years), and weight was $18.9 \mathrm{~kg}$ (range, 11-35 kg). One patient died on the operating table (graft failure and hemorrhage). In 5 survivors the median intensive care unit stay was 10 days (range, 8-61 days). On follow-up of 6 to 81 months, there have been no subsequent deaths, and the quality of life in survivors is good.

Conclusion: Rescue cardiac transplantation in the setting of an early failure of the Fontan-type circulation and end-stage cardiac failure is an effective treatment option and can be performed with acceptable early mortality and encouraging short-term to medium-term results.

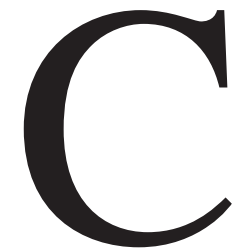
ardiac transplantation in infants and children has evolved considerably over the past 2 decades. ${ }^{1-5}$ Five-year survival is currently approaching $90 \%$ in the cardiomyopathy group and $80 \%$ in those with congenital heart disease as a primary diagnosis. ${ }^{1,4,6}$

In 1971, the Fontan procedure was initially conceived for a patient with tricuspid atresia. ${ }^{7}$ Since then, it has been established as a definitive palliation for cardiac anomalies with a single functional ventricle or 2 ventricles with anatomy unsuitable for biventricular repair. ${ }^{8-10}$ Early failure of the Fontan circulation within 30 days of an operation is a potentially fatal complication. ${ }^{11,12}$ The conventional approach in this situation is to take down the Fontan 
TABLE 1. Patient characteristics

\begin{tabular}{|c|c|c|c|c|c|c|}
\hline Patients & Patient 1 & Patient 2 & Patient 3 & Patient 4 & Patient 5 & Patient 6 \\
\hline Sex & Male & Male & Male & Male & Male & Female \\
\hline Diagnosis & $\begin{array}{l}\text { Dextrocardia, } \\
\text { CAVSD, PS, } \\
\text { LV } \\
\text { hypoplasia }\end{array}$ & $\begin{array}{l}\text { PA-IVS, RV } \\
\text { hypoplasia, RV } \\
\text { to coronary } \\
\text { fistula }\end{array}$ & $\begin{array}{l}\text { RAI, CAVSD, TGA, PA, } \\
\quad \text { bilateral SVCs }\end{array}$ & $\begin{array}{l}\text { TGA, VSD, PS, LV } \\
\text { hypoplasia }\end{array}$ & $\begin{array}{l}\text { CAVSD, CoA, LV } \\
\text { hypoplasia }\end{array}$ & $\begin{array}{l}\text { Severe } \\
\text { Epstein, } \\
\text { large ASD, } \\
\text { TVR }\end{array}$ \\
\hline $\begin{array}{l}\text { Previous } \\
\text { operations }\end{array}$ & $\begin{array}{c}\text { Classical } \\
\text { RMBT } \\
\text { shunt }\end{array}$ & $\begin{array}{l}\text { RMBT shunt, BDG } \\
\text { shunt; repair of } \\
\text { RPA }\end{array}$ & $\begin{array}{l}\text { LMBT shunt, bilateral } \\
\text { BDG shunt }\end{array}$ & $\begin{array}{l}\text { RMBT shunt, BDG } \\
\text { shunt }\end{array}$ & $\begin{array}{l}\text { CoA repair-PAB, } \\
\text { BDG shunt }\end{array}$ & None \\
\hline \multicolumn{7}{|l|}{$\begin{array}{l}\text { Preoperative HD } \\
(\mathrm{mm} / \mathrm{Hg})\end{array}$} \\
\hline PAM & 13 & 10 & 15 & 15 & 14 & - \\
\hline SVEDP $\left(\mathrm{U} / \mathrm{m}^{2}\right)$ & 4 & 8 & 12 & 11 & 11 & - \\
\hline TPR & 2.2 & 4.0 & 3.9 & 3.2 & 4.0 & - \\
\hline PAVR & 1.4 & 1.9 & 2.6 & 1.6 & 3.5 & - \\
\hline $\begin{array}{l}\text { Age at } \\
\text { operation (y) }\end{array}$ & 12 & 4.3 & 7.3 & 7.6 & 3.0 & 6.5 \\
\hline Operation & $\begin{array}{l}\text { TCPC, lateral } \\
\text { tunnel }\end{array}$ & $\begin{array}{l}\text { Extracardiac } \\
\text { Fontan, 18-mm } \\
\text { PTFE tube }\end{array}$ & $\begin{array}{c}\text { Extracardiac Fontan, } \\
20-\mathrm{mm} \text { PTFE tube }\end{array}$ & $\begin{array}{l}\text { One-an-a-half } \\
\text { repair, IVC } \\
\text { Senning to LV, } \\
\text { LV to PA } \\
\text { conduit, VSD } \\
\text { closure }\end{array}$ & $\begin{array}{l}\text { Extracardiac } \\
\text { Fontan, 18-mm } \\
\text { PTFE tube, } \\
\text { LPA plasty }\end{array}$ & $\begin{array}{l}\text { One-and-a- } \\
\text { half repair, } \\
\text { tricuspid } \\
\text { valve } \\
\text { repair, BDG } \\
\text { shunt, ASD } \\
\text { closure }\end{array}$ \\
\hline Fenestration & $4 \mathrm{~mm}$ & No & $5 \mathrm{~mm}$ & & $4 \mathrm{~mm}$ & \\
\hline $\begin{array}{l}\text { Mechanisms for } \\
\text { failure }\end{array}$ & $\begin{array}{l}\text { SV } \\
\text { dysfunction, } \\
\text { common } \\
\text { AVVR, } \\
\text { atrial } \\
\text { tachycardia }\end{array}$ & $\begin{array}{l}\text { LV dysfunction, } \\
\text { ventricular } \\
\text { tachycardia }\end{array}$ & $\begin{array}{l}\text { SV dysfunction, } \\
\text { common AVVR }\end{array}$ & $\begin{array}{l}\text { SV dysfunction, } \\
\text { systemic AVVR, } \\
\text { SVC syndrome }\end{array}$ & $\begin{array}{l}\text { SV dysfunction, } \\
\text { left phrenic } \\
\text { Palsy }\end{array}$ & $\begin{array}{l}\text { LV } \\
\text { dysfunction, } \\
\text { severe PR }\end{array}$ \\
\hline Intervention & Nil & $\begin{array}{l}\text { Fenestration, } \\
\text { cardiac ECMO }\end{array}$ & Nil & $\begin{array}{l}\text { RPA banding, } \\
\text { catheter } \\
\text { occlusion of } \\
\text { RPA band }\end{array}$ & Nil & Nil \\
\hline OP-TXP (d) & 180 & 16 & 6 & 135 & 12 & 56 \\
\hline TXP W/L & 21 & 14 & 3 & 16 & 2 & 27 \\
\hline
\end{tabular}

CAVSD, Complete atrioventricular septal defect; $P S$, pulmonary stenosis; $L V$, left ventricle; $P A$, pulmonary atresia; IVS, intact ventricular septum; $R V$, right ventricle; $R A I$, right atrial isomerism; $T G A$, transposition of the great arteries; $S V C$, superior vena cava; VSD, ventricular septal defect; CoA, coarctation of aorta; $A S D$, atrial septal defect; TVR, total vascular resistance; $R M B T$, right modified Blalock-Taussig; $B D G$, bidirectional Glenn; $L M B T$, left modified Blalock-Taussig; $P A B$, pulmonary artery band; $H D$, hemodynamics; $P A M$, pulmonary artery mean pressure; SVEDP, systemic ventricular end-diastolic pressure; TPR, total pulmonary resistance; PAVR, pulmonary arteriolar resistance; SV, systemic ventricle; TCPC, total cavopulmonary connection; PTFE, polytetrafluoroethylene (Gore-Tex; W. L. Gore \& Associates, Inc, Flagstaff, Ariz); IVC, inferior vena cava; $L P A$, left pulmonary artery; AVVR, atrioventricular valve regurgitation; $P R$, pulmonary resistance; $E C M O$, extracorporeal membrane oxygenation; $R P A$, right pulmonary artery; $T X P$, transplantation; $W / L$, waiting list.

circulation. This approach, however, is associated with very high mortality and an uncertain long-term future. ${ }^{11,12}$ An alternative strategy of cardiac transplantation as a life-saving and life-enhancing therapy seems attractive because it provides normal cardiac anatomy and physiology. Cardiac transplantation for late failure of the Fontan circulation has been reported previously, with variable success. ${ }^{4,13-16}$ Indications for transplantation in this group are protein-losing enteropathy, intractable atrial arrhythmia, and systemic ventricular dysfunction. Early failure of the Fontan-type circulation is a life-threatening complication, and the therapeutic options are limited. To our knowledge, this is the first series of rescue cardiac transplantation for early failure of the Fontan-type circulation in children. Technical challenges in peritransplant intensive care and cardiac transplantation surgery are discussed. 
TABLE 2. Pretransplantation status

\begin{tabular}{|c|c|c|c|c|c|c|}
\hline Patients & Patient 1 & Patient 2 & Patient 3 & Patient 4 & Patient 5 & Patient 6 \\
\hline Weight (kg) & 35 & 17 & 21 & 20.8 & 11 & 15 \\
\hline Respiratory support & Ventilation & Ventilation & $\begin{array}{l}\text { Ventilation + } \\
\quad \text { NO }\end{array}$ & $\begin{array}{l}\text { Ventilation }+ \\
\quad \text { NO }\end{array}$ & $\begin{array}{l}\text { Ventilation }+ \\
\quad \text { NO }\end{array}$ & Ventilation \\
\hline \multicolumn{7}{|l|}{$\begin{array}{l}\text { Inotropes }(\mu \mathrm{g} \cdot \\
\left.\qquad \mathrm{kg}^{-1} \cdot \min ^{-1}\right)\end{array}$} \\
\hline Dobutamine & 10 & 10 & - & 10 & - & 10 \\
\hline Milrinone & 0.75 & 0.7 & 0.5 & 0.75 & 0.75 & 0.75 \\
\hline Epinephrine & - & 0.1 & 0.15 & 0.1 & 1.0 & 0.05 \\
\hline Norepinephrine & - & 0.2 & 0.1 & - & - & - \\
\hline Dopamine & - & 4.0 & - & - & - & - \\
\hline \multicolumn{7}{|l|}{ Comorbidity } \\
\hline Pleural effusion & - & ++ & ++ & ++ & ++ & ++ \\
\hline Ascites & - & - & ++ & ++ & - & - \\
\hline $\begin{array}{l}\text { Renal } \\
\text { impairment }\end{array}$ & Ur: 14, Cr: 120 & Ur: 22, Cr: 278 & Ur: 9.0, Cr: 99 & Ur: 11.4, Cr: 59 & Ur: 12, Cr: 75 & Ur: 8, Cr: 81 \\
\hline $\begin{array}{l}\mathrm{GFR}\left(\mathrm{mL} \cdot \min ^{-1}\right. \\
\left.\quad \cdot 1.74 \mathrm{~m}^{-2}\right)\end{array}$ & 44 & 15 & 48 & 80 & 49 & 50 \\
\hline Liver impairment & $\begin{array}{l}\text { Bili: 89, } \\
\text { ALP: 124, } \\
\text { ALT: } 167\end{array}$ & - & $\begin{array}{l}\text { Bili: 21, } \\
\text { ALP: } 61, \\
\text { ALT: } 11\end{array}$ & $\begin{array}{l}\text { Bili: 16, } \\
\text { ALP: } 98 \\
\text { ALT: } 72\end{array}$ & $\begin{array}{l}\text { Bili: } 47, \\
\text { ALP: } 43 \\
\text { ALT: } 83\end{array}$ & $\begin{array}{l}\text { Bili: 174, } \\
\text { ALP: } 104, \\
\text { ALT: } 42\end{array}$ \\
\hline Coagulopathy & - & - & - & - & ++ & ++ \\
\hline Sepsis & - & - & - & CRP: 212 & - & - \\
\hline Other interventions & & $\begin{array}{l}\text { Pleural } \\
\text { drainage, } \\
\text { cardiac } \\
\text { ECMO }\end{array}$ & $\begin{array}{l}\text { Pleural } \\
\text { drainage, } \\
\text { peritoneal } \\
\text { drainage, } \\
\text { TPN }\end{array}$ & $\begin{array}{l}\text { Pleural } \\
\text { drainage, } \\
\text { peritoneal } \\
\text { drainage, } \\
\text { TPN }\end{array}$ & $\begin{array}{l}\text { Pleural drainage, } \\
\text { peritoneal } \\
\text { dialysis, } \\
\text { cardiac, } \\
\text { pacing, } \\
\text { surface } \\
\text { cooling }\end{array}$ & $\begin{array}{l}\text { Pleural } \\
\text { drainage }\end{array}$ \\
\hline \multicolumn{7}{|l|}{$\begin{array}{l}\text { Cardiac } \\
\quad \text { catheterization }\end{array}$} \\
\hline Fontan pathways & $\begin{array}{l}\text { No } \\
\text { obstruction }\end{array}$ & $\begin{array}{l}\text { No } \\
\text { obstruction }\end{array}$ & $\begin{array}{l}\text { No } \\
\text { obstruction }\end{array}$ & $\begin{array}{l}\text { No } \\
\text { obstruction }\end{array}$ & $\begin{array}{l}\text { No } \\
\text { obstruction }\end{array}$ & $\begin{array}{l}\text { No } \\
\text { obstruction }\end{array}$ \\
\hline Fenestration & Patent & Patent & Patent & - & Patent & - \\
\hline PAM (mm Hg) & 14 & & 21 & Rt: 20, Lt: 28 & 25 & 19 \\
\hline SVEDP $(\mathrm{mm} \mathrm{Hg})$ & 12 & & 12 & 16 & 12 & 11 \\
\hline Echocardiography & $\begin{array}{l}\text { Poor SV } \\
\text { function, } \\
\text { severe } \\
\text { AVVR }\end{array}$ & $\begin{array}{l}\text { Poor LV } \\
\quad \text { function }\end{array}$ & $\begin{array}{l}\text { Poor SV } \\
\text { function, } \\
\text { moderate } \\
\text { AVVR }\end{array}$ & $\begin{array}{l}\text { Poor SV } \\
\text { function, } \\
\text { severe } \\
\text { AVVR }\end{array}$ & $\begin{array}{l}\text { Poor SV } \\
\text { function, } \\
\text { moderate } \\
\text { AVVR }\end{array}$ & $\begin{array}{l}\text { Poor LV } \\
\text { function, } \\
\text { severe } \\
\text { PR }\end{array}$ \\
\hline
\end{tabular}

NO, Nitric oxide; $U r$, serum urea level in millimoles per liter; $C r$, serum creatinine in millimoles per liter; GFR, glomerular filtration rate; Bili, serum bilirubin in micromoles per liter; $A L P$, serum alkaline phosphatase in units per liter; $A L T$, serum alanine transaminase in units per liter; $C R P, C$-reactive protein in milligrams per liter; $E C M O$, extracorporeal membrane oxygenation; $T P N$, total parenteral nutrition; $P A M$, pulmonary artery mean pressure; $R t$, right; $L t$, left; $S V E D P$, systemic ventricular end-diastolic pressure; SV, systemic ventricle; AVVR, atrioventricular valve; $P R$, pulmonary regurgitation.

\section{Patients and Methods}

Between 1985 and 2003, a total of 110 cardiac transplantations were performed in 107 children less than 16 years of age. Six patients described in this report were referred to our institution for cardiac transplantation assessment after early failure of the Fontantype circulation.

\section{Patient Characteristics}

Table 1 summarizes the clinical and hemodynamic data on these patients. Four patients had undergone a modified Fontan operation, and the remaining 2 patients had undergone a one-and-a-halfventricle repair operation. All 6 patients were separated from cardiopulmonary bypass after completion of the operation. Four patients (patients 2, 3, 5, and 6) were referred for cardiac transplantation after failure in weaning off ventilatory and inotropic support and progressive cardiac failure in the early postoperative period. Patients 1 and 4 were noted to have severe systemic ventricular dysfunction with significant systemic atrioventricular valve regurgitation in the early postoperative period. Onset of intractable atrial arrhythmias in patient 1 and superior vena caval 
TABLE 3. Donor and recipient sizes

\begin{tabular}{|c|c|c|c|c|}
\hline \multirow{3}{*}{$\frac{\text { Patients }}{1}$} & \multirow{2}{*}{\multicolumn{2}{|c|}{$\begin{array}{c}\text { Recipient } \\
\text { Height } \\
(\mathbf{c m}) / \text { weight }(\mathbf{k g})\end{array}$}} & \multirow{2}{*}{\multicolumn{2}{|c|}{$\begin{array}{c}\text { Donor } \\
\text { Height } \\
(\mathbf{c m}) / \text { weight }(\mathrm{kg})\end{array}$}} \\
\hline & & & & \\
\hline & 156 & 35 & 160 & 76 \\
\hline 2 & 102 & 17 & 154 & 47 \\
\hline 3 & 119 & 21 & 157 & 55 \\
\hline 4 & 118 & 20.8 & 160 & 65 \\
\hline 5 & 92 & 11 & 137 & 26 \\
\hline 6 & 102 & 15 & 125 & 25 \\
\hline
\end{tabular}

hypertension syndrome in patient 4 led to end-stage cardiac failure and referral for cardiac transplantation. All 6 patients received a cardiac transplant; the median interval from operation to transplantation was 36 days (range, 6-180 days). There were no deaths while waiting on the transplant list after early failure of the Fontan-type circulation.

\section{Pretransplantation Status}

Table 2 summarizes the clinical condition of these patients before cardiac transplantation and the details of multiorgan support. Cardiac catheterization was performed in 5 patients and revealed unobstructed cavopulmonary pathways and increased systemic venous pressure. Fenestration was patent in the 3 patients and introduced in the Fontan circulation after early Fontan failure in patient 2. The mechanism for the early failure of the Fontan-type circulation in this group of patients was multifactorial, predominantly being a combination of systemic ventricular dysfunction (fractional shortening $<10 \%$ ) and significant systemic atrioventricular valve regurgitation (grade III-IV). Intractable cardiac arrhythmias were present in 2 patients. In addition, superior vena caval hypertension syndrome in patient 4 and severe pulmonary regurgitation in patient 6 were contributory factors for the failure of one-and-a-half-ventricle repair.

\section{Transplant Operation}

The technique of the transplant operation in this scenario differs from the usual technique in 2 respects: the pulmonary arteries require reconstruction, and the systemic venous drainage might require redirection. The pulmonary artery reconstruction was undertaken with bovine pericardium in 5 patients and with pulmonary homograft in 1 patient. In patient 3 the left superior vena cava was anastomosed to the right atrial appendage, with the right superior vena cava (SVC) being anastomosed to the donor SVC. We deliberately oversized the donor heart because of concerns regarding increase in pulmonary vascular resistance (Table 3). Postoperatively, all the patients were managed with the standard pediatric protocol of immunosuppression. This included induction therapy with equine antithymocyte globulin in 4 patients and interleukin 2 antagonist in 2 patients. Maintenance immunosuppression was achieved with a combination of cyclosporine (INN: ciclosporin), azathioprine, and steroids.

\section{Results}

\section{Early Results}

One patient died on the operating table as a result of graft failure and hemorrhage. Posttransplantation morbidity (Table 4) included gut dysfunction-bowel perforation requiring surgical intervention and prolonged dependence on parenteral nutrition in patient 3 , acute renal failure requiring venovenous hemofiltration in patient 5 , and prolonged ventilatory dependence necessitating tracheostomy in patients 3 and 5. Cyclosporine toxicity causing seizures was seen in patient 6 . The intensive care unit stay ranged from 8 to 61 days (median, 10 days).

\section{Late Results}

On follow-up of 6 to 81 months, there have been no subsequent deaths. Tracheostomy decannulation was accomplished in patients 3 and 5 before hospital discharge, and patient 3 underwent reversal of the ileostomy 3 months after transplantation. Quality of life in 5 survivors is good, with normal heart function and no evidence of rejection on endomyocardial biopsy.

\section{Discussion}

\section{Early Fontan Failure}

Failure of the Fontan circulation in the early postoperative period is a potentially fatal complication. In a series of 702

TABLE 4. Posttransplantation complications

\begin{tabular}{|c|c|c|c|c|c|c|}
\hline Patients & Patient 1 & Patient 2 & Patient 3 & Patient 4 & Patient 5 & Patient 6 \\
\hline Comorbidity & $\begin{array}{l}\text { Bilateral } \\
\text { empyema }\end{array}$ & $\begin{array}{l}\text { RV failure, } \\
\text { bleeding }\end{array}$ & $\begin{array}{l}\text { Bowel perforation, URT } \\
\text { obstruction, } \\
\text { chylothorax, sepsis }\end{array}$ & Nil & $\begin{array}{l}\text { ARF, URT } \\
\text { obstruction, } \\
\text { sepsis }\end{array}$ & $\begin{array}{l}\text { Seizures, } \\
\text { hyperbilirubinemia }\end{array}$ \\
\hline Interventions & $\begin{array}{l}\text { Pleural } \\
\text { drainage }\end{array}$ & Nil & $\begin{array}{l}\text { Ileostomy, tracheostomy, } \\
\text { pleural drainage }\end{array}$ & Nil & $\begin{array}{l}\text { Hemofiltration, } \\
\text { tracheostomy }\end{array}$ & Nil \\
\hline ICU stay $(d)$ & 10 & - & 31 & 8 & 61 & 8 \\
\hline Outcome & Survival & Death & Survival & Survival & Survival & Survival \\
\hline Follow-up (mo) & 81 & - & 15 & 9 & 8 & 6 \\
\hline $\begin{array}{l}\text { Functional class } \\
\text { (NYHA) }\end{array}$ & Class I & & Class I & Class I & Class I & Class I \\
\hline
\end{tabular}

$R V$, Right ventricle; URT, upper respiratory tract; $A R F$, acute renal failure; ICU, intensive care unit; NYHA, New York Heart Association. 
TABLE 5. Algorithm for management of early Fontan failure

Early Fontan failure
$\downarrow$
Identify the mechanism for the failure (ECG/echocardiography/
cardiac catheter)
$\downarrow$
1. Arrhythmia: medications/ablation procedure
2. AVVR: valve repair/replacement
3. Systemic venous hypertension
A. Obstruction to Fontan pathways: relief of obstruction
stenting/surgery
B. Increased pulmonary vascular resistance: Fontan
fenestration/? pulmonary vasodilators/take down to AP shunt
4. Pump failure: Inotropes/mechanical support/cardiac
transplantation
5. $4+1 / 2 / 3$ : Inotropes/mechanical support/cardiac transplant

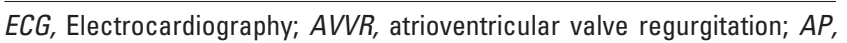
aortopulmonary.

consecutive patients who underwent modified Fontan operations at the Mayo Clinic, ${ }^{11}$ early failure was seen in 104 $(14.8 \%)$ patients. Successful takedown of the repair was performed in 6 patients, and the remaining 98 patients died in the early postoperative period. In a similar study of the first 500 patients undergoing the modified Fontan operation at the Children's Hospital Boston, ${ }^{12}$ early failure was noted in $84(16.8 \%)$ patients. From this group, takedown of the operation was successful in 10 patients: 20 patients died with the takedown operation, and the remaining 54 patients died with Fontan circulation.

In the current era, creation of smaller aortopulmonary shunts, attention to systemic outflow tract obstruction and atrioventricular valve regurgitation, staging of the Fontan procedure, extracardiac Fontan modification, routine use of fenestration, and modified ultrafiltration during cardiopulmonary bypass are the strategies responsible for the significant decrease in the incidence of early Fontan failures, despite a widening application of the Fontan procedure to high-risk patients. ${ }^{11,12,17,18}$

\section{Pre-Fontan Hemodynamic Assessment}

Early failure of the Fontan-type operations, despite apparently satisfactory preoperative assessment, highlights the limitations of the techniques of hemodynamic and ventricular function assessment in these patients. Current techniques of hemodynamic assessment in this group of patients are often limited by low pulmonary blood flow and do not allow assessment of pulmonary vasculature under different loading conditions. M-mode and cross-sectional echocardiography are conventionally used to evaluate ventricular volume and function, and their accuracy depends on the ability to obtain a desired cross-sectional view and accurate geometric volume assumption. They are of limited value in the context of a functioning single ventricle because of complex structural geometry and numerous variations in the ventricular morphology. Stumper and colleagues ${ }^{19}$ have proposed a catheter technique to provide a 2-point hemodynamic assessment of the pulmonary vasculature before the Fontan operation. Ventricular time-volume curves obtained by means of radionuclide angiography,${ }^{20}$ magnetic resonance imaging, ${ }^{21}$ or real-time 3 -dimensional echocardiography ${ }^{22}$ are likely to provide reliable quantitative data on the global ventricular performance in the future.

\section{Management of Early Fontan Failure}

The pathophysiology of the early failure of the Fontan circulation is characterized by a combination of increased systemic venous pressure and a low cardiac output state. This initiates a cascade of events that results in tissue edema, hypoxia, and organ hypoperfusion, culminating in multiorgan failure and death. Early cardiac catheterization is mandatory to exclude fenestration occlusion, obstruction to the cavopulmonary pathways, and assessment of transpulmonary gradient.

Our ventilation strategy was aimed at maintenance of functional residual capacity while minimizing mean airway pressure to keep pulmonary vascular resistance at as low a level as possible, thereby optimizing pulmonary blood flow and ventricular preload. Three patients in this series also received nitric oxide. Pleural and peritoneal effusions reduce chest compliance and were aggressively drained. We preferred a combination of phosphodiesterase inhibitor (milrinone) and a catecholamine (dobutamine or epinephrine) for inotropic support in these patients. Milrinone has been shown to have beneficial effects after pediatric cardiac surgery and has favorable effects on pulmonary vascular resistance. ${ }^{23}$ Minimizing exogenous use of catecholamine might have particular benefit for these patients in view of the adverse effects of catecholamines on splanchnic blood flow, ${ }^{24}$ as well as adrenoreceptor downregulation before transplantation. Multiorgan dysfunction can manifest as renal failure, gastrointestinal dysfunction, and hepatic dysfunction necessitating meticulous multidisciplinary intensive care management. We recommend early use of parenteral nutrition in combination with low-dose trophic volumes of enteral feeding and selective decontamination of the digestive tract to prevent gastrointestinal malfunction. Tissue hypoxia, edema, and loss of proteinaceous exudates render these patients susceptible to infection. A high degree of suspicion for sepsis is therefore required coupled with rigorous microbiologic surveillance.

Mechanical circulatory support for patients with failing Fontan circulation has been described. ${ }^{25,26}$ A recent report describes the use of extracorporeal membrane oxygenation as an effective mechanical circulatory support for patients with failing Fontan circulation. ${ }^{27}$ This approach can be used as a short-term resuscitative measure as a bridge to recov- 
ery. Alternatively, it can be used as a stabilization maneuver as a bridge to transplantation. Morbidity and mortality associated with mechanical support for the failing Fontan circulation is still substantial, ${ }^{25-27}$ and the outcome is particularly unfavorable in patients with progressive multisystem organ dysfunction. Patient 2 in our series was bridged to transplantation with extracorporeal membrane oxygenation. In addition, 2 other patient in our series were electively cooled to a core temperature of $34^{\circ} \mathrm{C}$ to $35^{\circ} \mathrm{C}$ to reduce systemic oxygen consumption when their own oxygen-delivery capability was severely compromised.

On the basis of the predominant mechanism for the failure, we suggest an algorithm for the management of early Fontan failure (Table 5). In our patients we decided to go down the cardiac transplantation route because the mechanism for the failure of the Fontan-type circulation was multifactorial, there were no other viable surgical options available, and the patients were in end-stage cardiac failure with progressive multisystem organ dysfunction.

\section{Cardiac Transplantation for Early Fontan Failure}

Heart transplantation in the setting of a failing Fontan circulation is technically challenging. ${ }^{4,15,16}$ It requires reconstruction of pulmonary arteries, redirection of systemic venous connections, and appropriate siting of what is frequently an oversized heart. Use of oversized donor hearts has been shown to be safe for pediatric cardiac transplantation. ${ }^{28,29} \mathrm{We}$ also used oversized donor hearts with a size mismatch of up to $300 \%$ relative to the recipient, which allowed us to use the available donors. The adverse consequences of this approach are delayed sternal closure, persistent left lower lobe collapse, and systemic hypertension. In contrast to our own results, the mortality of heart transplantation after Fontan failure has been reported by others to be as high as $44 \%$ to $66 \% .^{14,15}$ Our experience shows that rescue cardiac transplantation is a viable option in the setting of early failure of the Fontan-type circulation, and the short-term to medium-term results are encouraging. In the future, primary cardiac transplantation might be the preferred management option for a high-risk Fontan operation in childhood.

\section{Conclusion}

Cardiac transplantation, although technically challenging, is an effective treatment option in the event of early failure of the Fontan-type circulation in children. Early referral for transplant assessment should be sought in the event of early failure of the Fontan-type circulation to avoid multiorgan dysfunction-related morbidity and mortality and to allow for procurement of a suitable donor heart.

We thank Professor John Dark and Dr Kate Gould for their help in preparation of this article.

\section{References}

1. Bailey LL, Gundry SR, Razzouk AJ, Wang N, Sciolaro CM, Chiovrelli M. Bless the babies: one hundred fifteen late survivors of heart transplantation during the first year of life. J Thorac Cardiovasc Surg. 1993;105:805-15.

2. Weber SA. 15 years of pediatric heart transplantation at the university hospital of Pittsburgh: lessons learned and future prospects. Pediatr Transplant. 1997;1:8-21.

3. Fricker JF, Addonizio L, Bernstein D, Boucek M, Boucek R, Canter C, et al. Heart transplantation in children: indications. Pediatr Transplant. 1999;3:333-42.

4. Carey JA, Hamilton JR, Hilton CJ, Dark JH, Forty J, Parry G, et al. Orthotopic cardiac transplantation for the failing Fontan circulation. Eur J Cardiothoracic Surg. 1998;14(1):7-13.

5. West LJ, Pollock-Barziv SM, Dipchand AI, Lee KJ, Cordella CJ, Benson LN, et al. ABO-incompatible heart transplantation in infants. N Engl J Med. 2001;344(11):793-800.

6. Boucek MM, Edwards LB, Keck BM, Trulock EP, Taylor DO, Mohacsi PJ, et al. The Registry of the International Society of Heart and Lung Transplantation: sixth official paediatric report-2003. J Heart Lung Transplant. 2003;22:636-52.

7. Fontan F, Baudet E. Surgical correction of tricuspid atresia. Thorax. 1971;26:240-8.

8. Mayer JE, Hedson H, Jonas RA, Lang P, Fargas FJ, Cook N, et al. Extending the limits for modified Fontan procedures. J Thorac Cardiovasc Surg. 1986;92:1021-8.

9. Russo P, Danielson GK, Puga FJ, McGoon DC, Humes R. Modified Fontan procedure for biventricular hearts with complex forms of double-outlet right ventricle. Circulation. 1988;78(suppl III):20-5.

10. Freedom RM, Hamilton R, Yoo S-J, Mikailian H, Benson L, McCrindle B, et al. The Fontan procedure: analysis of cohorts and late complications. Cardiol Young. 2000;10:307-31.

11. Knott-Craig CJ, Danielson GK, Schaff HV, Puga FJ, Weaver AL, Driscoll DJ. The modified Fontan operation: an analysis of risk factors for early postoperative death or takedown in 702 consecutive patients from one institution. J Thorac Cardiovasc Surg. 1995;109:1237-43.

12. Gentles TL, Mayer JE, Gauvreau K, Newburger JW, Lock JE, Kupferschmid JP, et al. Fontan operation in five hundred consecutive patients: factors influencing early and late outcome. $J$ Thorac Cardiovasc Surg. 1997;114:376-91.

13. Bernstein D, Naftel DC, Hsu DT, Adonizio LJ, Blume ED, Gamberg PL, et al. Outcome of listing for cardiac transplantation for failed Fontan: a multi-institutional study [abstract]. J Heart Lung Transplant. 1998;18(1):69.

14. Petko M, Myung RJ, Wernovski G, Cohen MI, Rychik J, Nicolson SC, et al. Surgical reinterventions following the Fontan procedure. Eur J Cardiothorac Surg. 2003;24:255-9.

15. Michielon G, Parisi F, Squitieri C, Carotti A, Gagliardi G, Pasquini L, et al. Orthotopic heart transplantation for congenital heart disease: an alternative for high risk Fontan candidates. Circulation. 2003; 108(suppl II):140-9.

16. Gamba A, Merlo M, Fiocchi R, Terzi A, Mammana C, Sebastiani R, et al. Heart transplantation in patients with previous Fontan operations. J Thorac Cardiovasc Surg. 2004;127:555-62.

17. Mayer JE Jr, Bridges ND, Lock JE, Hanley FL, Jonas RA, Casteneda AR. Factors associated with marked reduction in mortality for Fontan operations in patients with single ventricle. J Thorac Cardiovasc Surg. 1992;103:441-51.

18. Mosca RS, Kulic TJ, Goldberg CS, Vermilion RP, Charpie JR, Crowley DC, et al. Early results of the Fontan procedure in one hundred consecutive patients with hypoplastic left heart syndrome. J Thorac Cardiovasc Surg. 2000;119:1110-8.

19. Stumper O, Chaudhari M, Miller P, de Giovanni JV, Wright JGC, Silove ED. Assessment of the pulmonary vasculature under different loading conditions prior to Fontan operation [abstract]. Cardiol Young. 1998;9(1): 15 .

20. Magorien DJ, Shaffer P, Bush CA, Magorien RD, Kolibash AJ, Leier $\mathrm{CV}$, et al. Assessment of left ventricular pressure-volume relations using gated radionuclide angiography, echocardiography, and micro 
manometer pressure recordings. A new method for serial measurements of systolic and diastolic function in man. Circulation. 1983;67(4):844-53.

21. Helbing WA, Rebergen SA, Maliepaard C, Hansen B, Ottenkamp J, Reiber J, et al. Quantification of right ventricular function with magnetic resonance imaging in children with normal hearts and with congenital heart disease. Am Heart J. 1995;130(4):828-37.

22. Mannaerts HF, Van Der Heide JA, Kamp O, Papavassiliu T, Marcus J, Beek A, et al. Quantification of left ventricular volumes and ejection fraction using freehand three-dimensional echocardiography; comparison with magnetic resonance imaging. J Am Soc Echocardiogr. 2003; 16(2):101-9.

23. Hoffman TM, Wernosky G, Atz AM, Kulik TJ, Nelson DP, Chang AC, et al. Efficacy and safety of milrinone in preventing low cardiac output syndrome in infants and children after corrective surgery for congenital heart disease. Circulation. 2003;107(7):996-1002.

24. Meier Hellmann A, Reinhart K, Bredle DL, Sakka SG. Therapeutic options for management of impaired gut function. Am Soc Nephrol. 2001;12(suppl):S65-9.
25. Hertzer R, Loebe M, Potapov EV, Weng Y, Stiller B, Henning B, et al. Circulatory support with pneumatic paracorporeal ventricular assist device in infants and children. Ann Thorac Surg. 1998;66(5):1498506.

26. Gajarski RJ, Mosca RS, Ohye RG, Bove EL, Crowley DC, Canter JR, et al. Use of extracorporeal life support as a bridge to paediatric cardiac transplantation. J Heart Lung Transplant. 2003;22:28-34.

27. Booth KL, Roth SJ, Thiagarajan RR, Almodovar MC, del Nido PJ, Laussen PC. Extra-corporeal membrane oxygenation support of the Fontan and bi-directional Glenn circulations. Ann Thorac Surg. 2004; 77:1341-8

28. Fullerton DA, Gundry SR, de Begona JA, Kawauchi M, Razzouk AJ, Bailey LL. The effects of donor-recipient size disparity in infant and pediatric heart transplantation. J Thorac Cardiovasc Surg. 1992;104: 1314-9.

29. Shaddy RE, Naftel DC, Kirklin JK, Boyle G, McGiffin DC, Tobwin JA, et al. Outcome of cardiac transplantation in children: survival in a contemporary multi-institutional experience. Circulation. 1996;94(suppl II): II69-73. 